\title{
MICROSCOPIC STUDIES ON MODIFIED WALL STRUCTURE AND LIGNIN TOPOCHEMISTRY IN XYLEM FIBRES OF POPLAR AFTER WOUNDING
}

\author{
Claus Frankenstein ${ }^{1}$, Uwe Schmitt ${ }^{2}$
}

In memoriam of Dr. Walter G. KAUMAN

\begin{abstract}
Information about fine structure following wounding in differentiating xylem tissue is still scarce. This study provides information on cell wall modifications with special emphasis on lignin distribution in xylem fibres of poplar differentiating at the time of wounding. Samples were collected from wounded Populus spp. trees after response periods of up to twenty-three months and processed for microscopic analyses. General studies on the wall structure of wound-adjacent xylem fibres were carried out with light and transmission electron microscopy, whereas lignin distribution patterns of these cells were examined by UV-microspectrophotometry.

Xylem fibres close to the wound and within a transition zone between differentiated xylem laid down prior to and tissue laid down after wounding developed a distinctively thicker secondary wall than normal fibres. These modified walls also showed a slightly higher lignin content, than normal and a heterogeneous lignin distribution in the middle lamella and the secondary wall.

Wounding in poplar induces a modified wall structure and lignin topochemistry in xylem fibres differentiating at the time of wounding. It is assumed that this wound response is part of the compartmentalization process and therefore contributes to an increased resistance.
\end{abstract}

Keywords: Wound reaction, poplar, Populus tremula L. $x$ P. tremuloides Michx., fibre cell wall, lignin distribution, UV-microspectrophotometry

\section{INTRODUCTION}

Hardwood lignin is a complex 3-dimensional co-polymer consisting mainly of guaiacyl and syringyl units. As a major cell wall component of xylem elements, lignin distribution, content and composition have a significant influence on technical wood properties as well as on decay resistance. It is therefore of interest is know how external stress factors such as like wounding influence cell wall ultra structure and lignification.

The defence mechanisms induced by different types of injury can be subdivided into active and passive mechanisms. These highly variable reactions have been subject of numerous investigations at macroscopic and microscopic levels (e.g. Sharon, 1973; Mullick, 1977; Shortle, 1979; Shigo, 1984; Schmitt and Liese, 1990, 1992, 1993; Liese and Dujesiefken, 1996; Pearce, 2000). Tree vitality, seasonal influences and the extent of wounding are factors which determine whether reactions are restricted to areas close to the wound or whether larger areas of the surrounding tissue are affected. Wounds affecting the cambial region often lead to the formation of callus tissue and subsequently, modified xylem and phloem (e.g. Liese and Dujesiefken, 1989; Fink, 1999; Grünwald et al., 2002). Within the xylem different

\footnotetext{
${ }^{1,2}$ Federal Research Centre for Forestry and Forest Products/Institute for Wood Biology and Wood Protection, Leuschnerstrasse 91, D-21031 Hamburg/Germany. Correspondig author: uschmitt@holz.uni-hamburg.de Received: December 21, 2005. Accepted: April 13, 2006.
} 
reaction patterns lead to compartmentalization of the wounded area (Sharon, 1973; Shigo and Marx, 1977; Bauch et al., 1980; Rademacher et al, 1984; Shigo 1984; Lowerts et al., 1986; Liese and Dujesiefken, 1996). The formation of a so, called boundary layer which is mainly characterized by the synthesis of phenolic compounds in parenchyma cells with subsequent extrusion into neighbouring cells, i. e. fibres and vessels, as well as the formation of tyloses are the most prominent compartmentalization mechanisms in hardwoods at the microscopic level (e.g. Schmitt and Liese, 1990; Pearce, 2000). Earlier studies on wound reactions in poplar mainly focused on reactions of the bark, such as the formation of the lignosuberized zone, new periderms and the influence of pressure on tissue differentiation (Kaufert, 1937; Soe, 1959; Brown and Sax, 1962; Trockenbrodt and Liese, 1991; Bucciarelli et al., 1999). The formation of a wound-callus and the wound induced alterations within the xylem of poplar have already been described at the light microscopic level (e.g. Buntrock, 1989; Frankenstein et al., 2005).

The following contribution is focused on the modification of xylem elements within a transition zone between differentiated xylem laid down prior to wounding and tissue laid down after wounding. Special emphasis is given to modifications of the cell wall ultrastructure and the lignin distribution, using light- and transmission electron microscopy as well as cellular UV-microspectrophotometry.

\section{MATERIAL AND METHODS}

Rectangular wounds of $10 \mathrm{~cm}$ x $10 \mathrm{~cm}$ were made on 07 July 2002 and 23 June 2003 by removing the bark from stems of four mature poplar trees (Populus spp.) using a saw and a chisel. Samples were collected from the lateral wound edge after 2, 4, 8, 10, 17, 62 and 95 weeks of wound response (Fig. 1). The wound tissue, the adjacent modified xylem and unaffected xylem were removed with a chisel and razor blades.

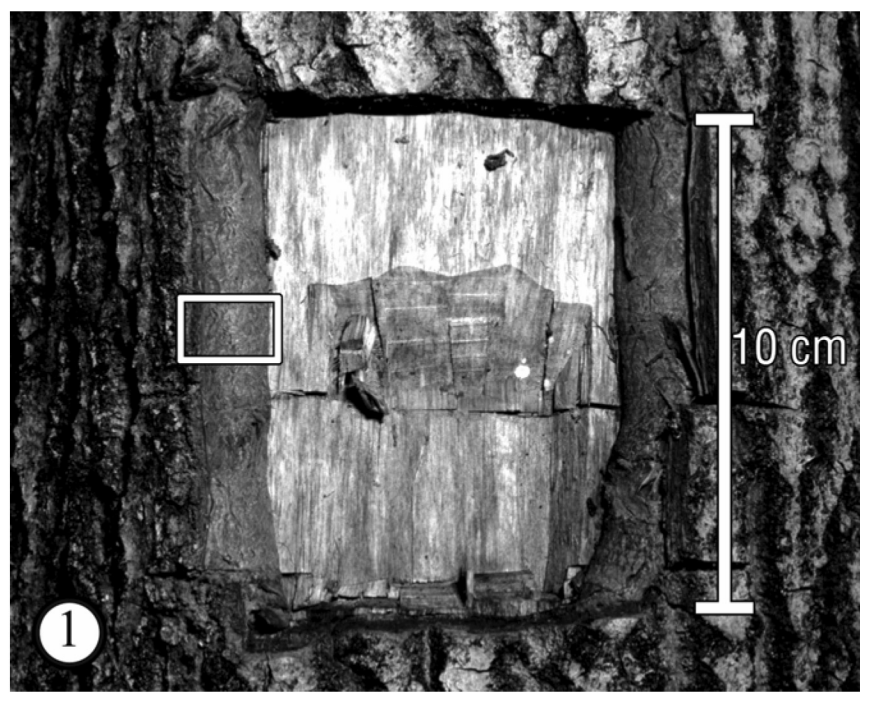

Figure 1 Callus formation at the lateral wound edges 95 weeks after wounding; the rectangle indicates the position of tissue sampling for microscopy and UV-microspectrophotometry.

\section{Microscopy}

For conventional light-microscopy, samples $\left(10 \times 10 \times 8 \mathrm{~mm}^{3}\right)$ were either fixed for three days in a phosphate-buffered solution of $37 \%$ formaldehyde, washed in distilled water, and embedded in polyethylene-glycol (PEG) or the fixed samples were dehydrated in a graded series of propanol and embedded in glycol methacrylate (Technovit 7100). $6 \mu \mathrm{m}$ thick transverse sections were cut with a 
rotary microtome and stained for $1.5 \mathrm{~h}$ with a standard Giemsa or a neutral red solution. Transverse sections $10 \mu \mathrm{m}$ thick were cut from the PEG embedded material with a sliding microtome and stained with a standard safranine/astra blue solution. Sections stained with neutral red were examined at wavelengths between $380-490 \mathrm{~nm}$.

For TEM, samples from the same series were reduced to a final size of $3 \times 3 \times 8 \mathrm{~mm}^{3}$, fixed for one day in a mixture of $5 \%$ glutaraldehyde and $8 \%$ paraformaldehyde, then partly postfixed with a $1 \%$ Osmium tetroxide solution, washed in $0.1 \mathrm{M}$ cacodylate buffer $(\mathrm{pH} 7.3)$, dehydrated in a graded series of acetone and embedded in Spurr's epoxy resin (Spurr, 1969).

Ultra-thin (80-100 nm) transverse sections were either double-stained with uranyl acetate and lead citrate or with potassium permanganate according to Donaldson (1992). The samples were examined with a Philips CM 12 TEM at an accelerating voltage of 60 or $80 \mathrm{kV}$.

\section{$U V$-microspectrophotometry}

For UV-microspectrophotometry, the samples were processed as described for TEM. $1 \mu \mathrm{m}$ transverse sections were prepared, mounted onto quartz slides, immersed in a drop of non-UV absorbing glycerine and covered with a quartz cover slip. Ultrafluar objectives lenses were used to observe the samples.

Scanning UV-microspectrophotometry was carried out using a ZEISS UMSP 80 microspectrophotometer equipped with an Osram high-pressure xenon lamp, an ultrafluar quartz condenser and a scanning stage enabling the determination of image profiles at a constant wavelength of $280 \mathrm{~nm}$ using the scan programme APAMOS (Automatic-Photometric-Analysis of Microscopic Objects by Scanning, Zeiss). This wavelength represents the typical absorbance maximum of lignified cell walls. The scan programme digitises rectangular tissue portions with a local geometrical resolution of $0.25 \mu \mathrm{m}^{2}$ and a photometrical resolution of 4096 grey scale levels, converted into 14 basic colours representing the measured absorbance intensities (Koch and Kleist, 2001).

Specimens were additionally analysed by point measurements with a spot size of $1 \mu \mathrm{m}^{2}$. The spectra were taken at wavelengths from 240 to $400 \mathrm{~nm}$ in $2 \mathrm{~nm}$ steps using the programme LAMWIN (Zeiss). These point measurements for a semi quantitative determination of the lignin content were automatically repeated 50 times at each spot for individual wall layers, i. e., compound middle lamella $(\mathrm{cml}), \mathrm{S} 2$ layers of the secondary wall (S2) and cell corners (cc).

\section{RESULTS \& DISCUSSION}

\section{Microscopy}

Light microscopy revealed that wounding induced the formation of modified xylem along a transition zone between xylem laid down prior to wounding and tissue laid down after wounding (Fig. 2). The number of fibres showing cell wall alterations decreased with increasing distance from the wound edge. Within this zone which was identified as xylem differentiating at the time of wounding, the formation of unusually thick-walled fibres was the most prominent structural feature (Figs. 3, 4). Septated fibres were regularly found in the transition zone (Fig. 5). Neighbouring cells of similar shape and therefore probably also septated fibres were in some cases filled with calcium-oxalate crystals. Corresponding to our observations, the formation of a tangential band of thick-walled, flattened fibres between newly formed and regular xylem induced by insertion of a pin, was reported for beech wood (Schmitt et al.,2000). Lowerts et al. (1986) reported the formation of sclereids within wound-associated xylem of Liriodendron tulipifera $\mathrm{L}$. as a regular feature. Electron microscopy showed that the affected poplar fibres, in contrast to unaffected fibres (Figs. 6,7), deposited additional secondary wall (S2) material leading to different patterns of wall thickenings with cell corners predominantly consisting of heavilystained material (Figs. 8-11). One group of xylem fibres developed an additional secondary wall layer, 
whereas a second group of fibres showed a continuously thickened S2 wall layer (Figs. 8, 9). In a third, smaller group, fibre walls developed a sclereid-like sublayering (Fig. 10). It seems that the stage of differentiation at the time of wounding had the strongest influence on the response of the different cell types. These structural alterations in the transition zone of poplar probably contribute to an increased resistance.

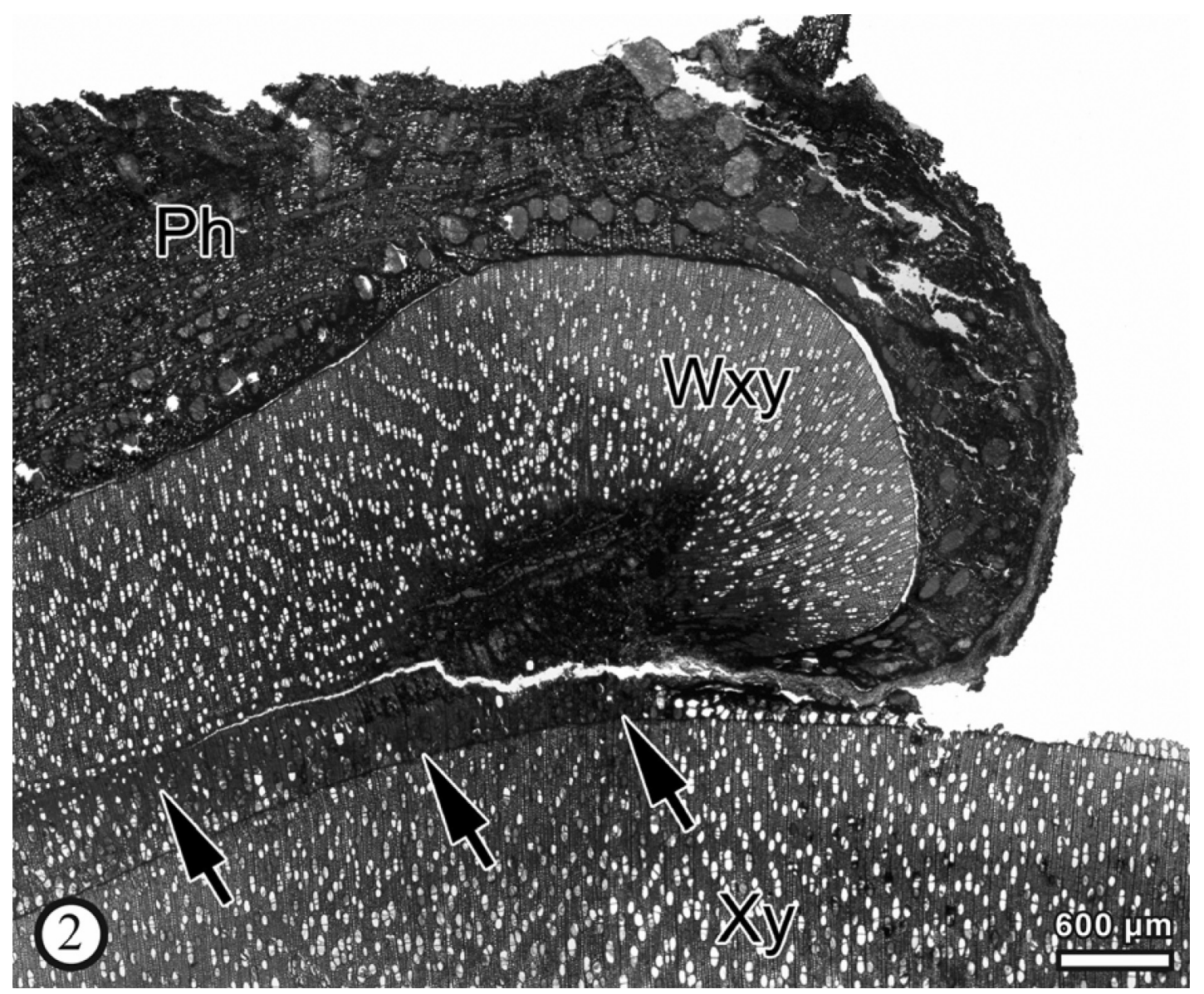

Figure 2. Transverse section through a wound callus and the modified transition zone between xylem laid down prior to and after wounding containing fibres with wound-induced wall thickenings (arrows), xylem (Xy), wound xylem (Wxy), phloem (Ph); light micrograph, safranin/astra blue staining. 

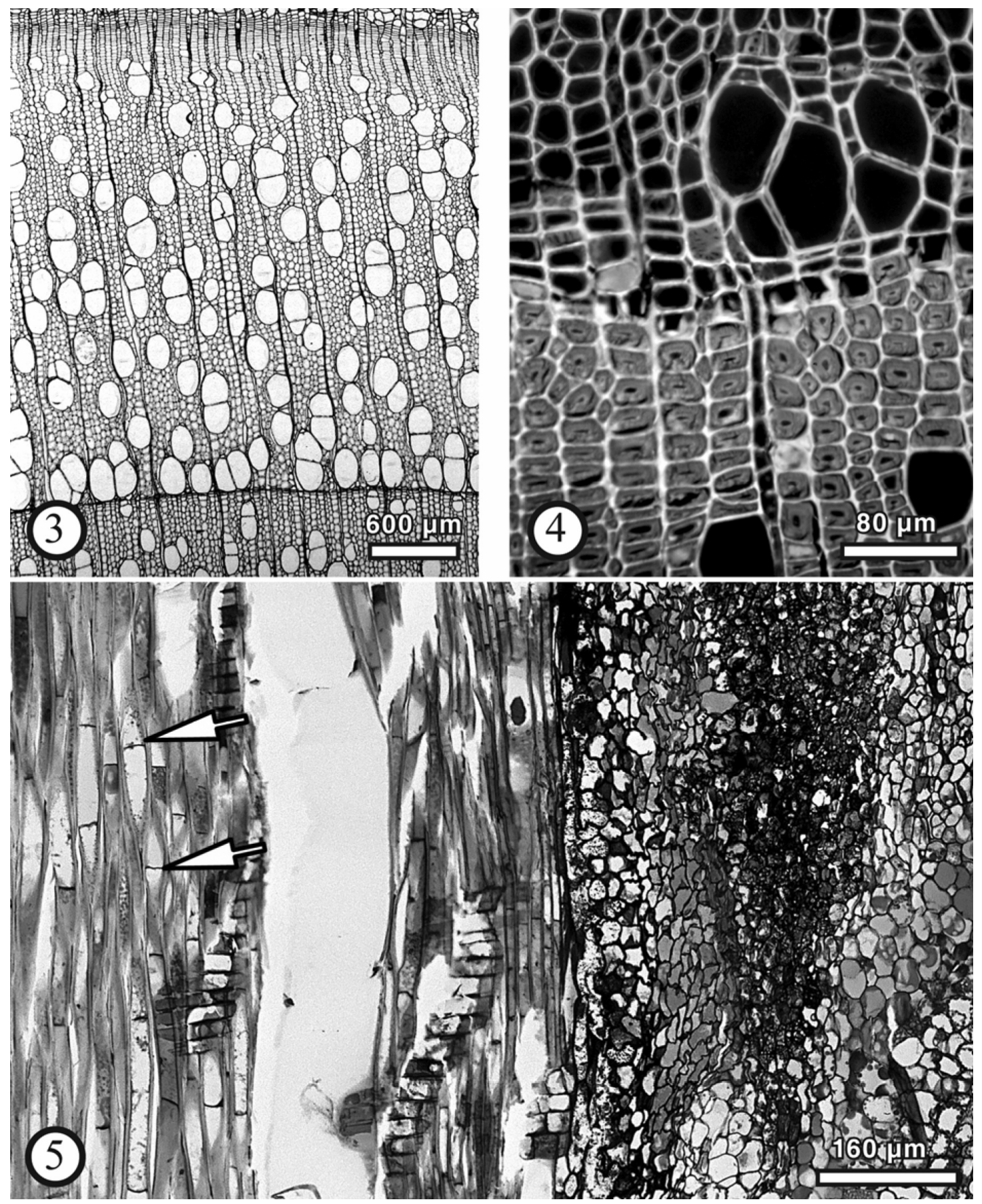

Figures 3-5 Light micrographs of unaffected and affected poplar tissues: 3) Transverse section through unaffected reference material of poplar showing thin-walled fibres; light micrograph, Giemsa staining; 4) Transverse section through modified xylem fibres with very thick secondary walls 8 weeks after wounding; the brighter areas indicating a higher lignin content; light micrograph, UV excitation after neutral red staining; 5) Radial section through a transition zone area with less distinct wall thickenings 8 weeks after wounding; septate fibres (arrows) are developed; light micrograph, Giemsa staining. 

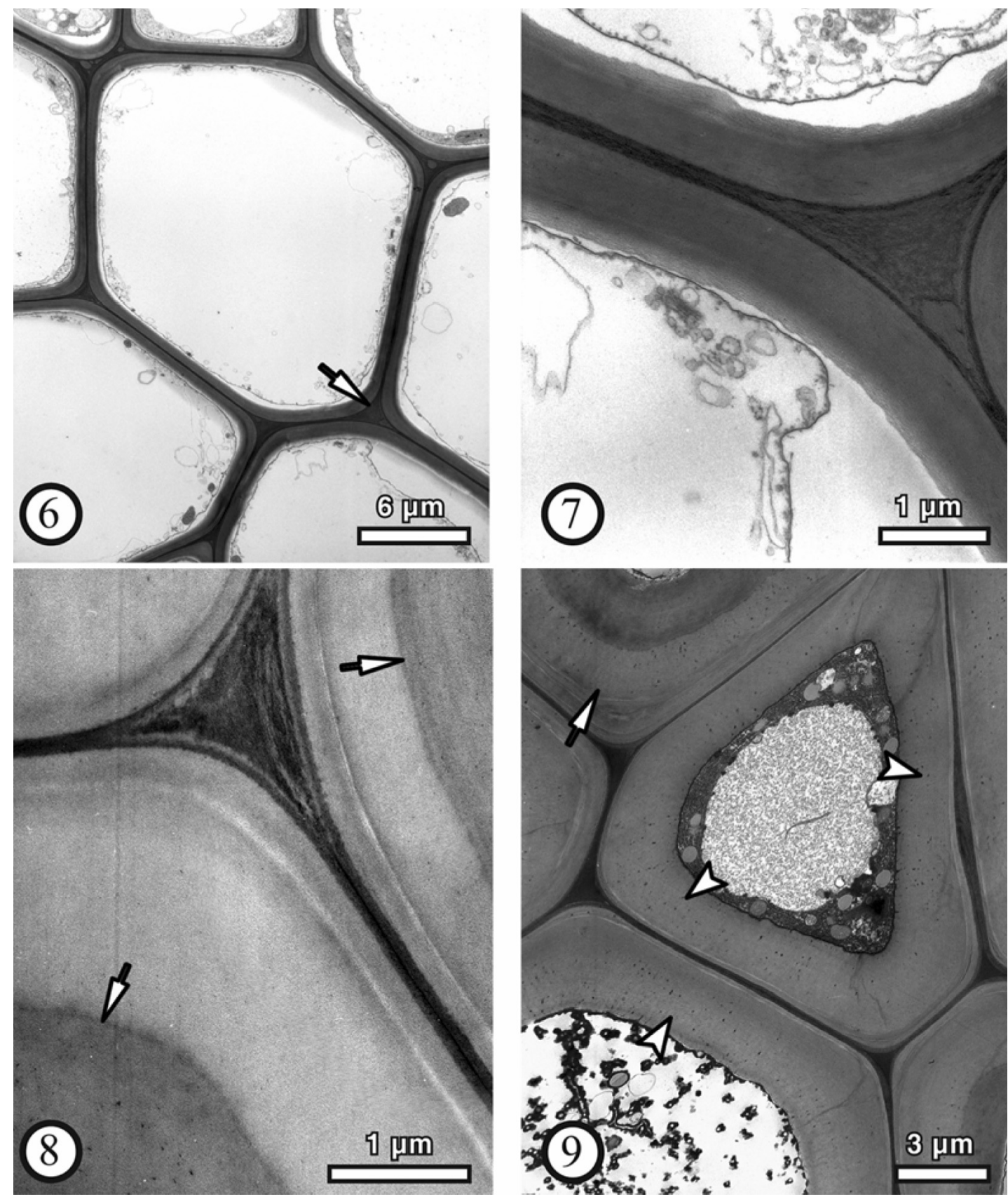

Figures 6-9 TEM micrographs of transverse sections through unmodified $(6,7)$ and modified $(8,9)$ poplar xylem: 6) typical thin-walled fibres, cell corners contain less electron dense material (arrow) when compared to wound-affected fibres; uranyl acetate and lead citrate staining; 7) cell corner of Fig. 6 (indicated there by an arrow) with a relatively low lignin content and a mottled lignin distribution; uranyl acetate and lead citrate staining; 8) modified xylem fibres with thick walls, containing only one additional secondary wall lamella (arrows), 10 weeks after wounding; potassium permanganate staining; 9) modified fibres of the transition zone with continuous secondary cell wall thickenings (without lamellation; arrowheads); fibre with more than one additional S2 lamella (arrow); cell corners contain heavily-stained material; duration of wound response four weeks; potassium permanganate staining. 

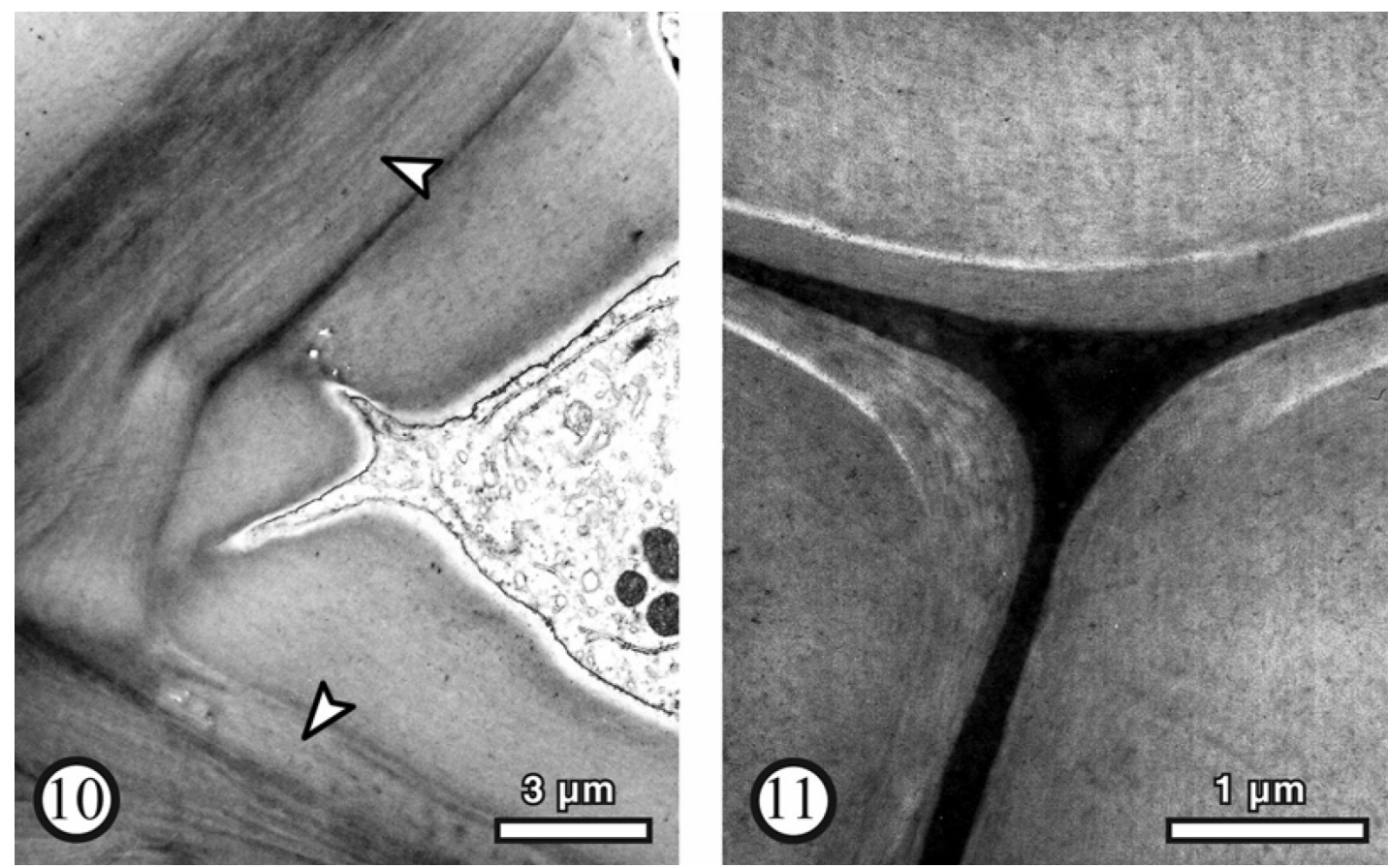

Figure 10, 11 TEM micrographs of transverse sections through modified xylem fibres: 10) woundinduced fibre with polylamellate secondary wall structure (arrowheads); duration of wound response 10 weeks; uranyl acetate and lead citrate staining; 11) cell corner of modified xylem fibres containing material with extremely high electron density; 10 weeks after wounding; potassium permanganate staining.

\section{UV microspectrophotometry}

UV microspectrophotometry has variously been proven as a reliable technique for the visualisation of lignin distribution and for its semiquantitative determination (e.g. Bland and Hillis, 1969; Scott et al., 1969; Fergus and Goring, 1970 a, b; Musha and Goring, 1975; Bauch et al., 1976; Bucciarelli et al., 1999; Fukazawa, 1992; Okuyama et al., 1998; Grünwald et al., 2001, 2002 a, b; Koch and Kleist, 2001; Takabe, 2002; Koch and Grünwald, 2004). For detailed information on the microdistribution of lignin within different wall layers, the tissues were first analysed by scanning UV-microspectrophotometry at a constant wavelength of $280 \mathrm{~nm}$ (Figs. 12-15).

The image profiles of unaffected fibres are characterised by thin S2 wall layers with relatively low and uniform absorbance values $\left(\mathrm{Abs}_{280 \mathrm{~nm}} 0.09\right.$ to $\mathrm{Abs}_{280 \mathrm{~mm}}$ 0.16). Higher absorbencies were recorded in the compound middle lamella $\left(\mathrm{Abs}_{280 \mathrm{~mm}} 0.16\right.$ to $\mathrm{Abs}_{280 \mathrm{~mm}} 0.23$ ) and in cell corners ( $\mathrm{Abs}_{280 \mathrm{~nm}} 0.23$ to $\mathrm{Abs}_{280 \mathrm{~nm}}$ 0.35 ) (Fig. 12). In terminal latewood fibres, the absorbance values increased slightly with maxima up to $\mathrm{Abs}_{280 \mathrm{~mm}} 0.23$ in the broader S2-layer, $\mathrm{Abs}_{280 \mathrm{~nm}} 0.35$ in the compound middle lamella and maxima of $\mathrm{Abs}_{280 \mathrm{~mm}} 0.67$ in cell corner regions. The uniform absorbance level within the S2-layer corresponds with earlier findings, describing a homogeneous lignin distribution across of the entire S2-layer (Saka and Goring, 1988; Koch and Kleist, 2001).

In Figures 13-15, the lignin distribution in walls of modified xylem cells within the transition zone is displayed. The secondary wall of the scanned modified fibres was much thicker in later stages of wound response (Figs. 13, 15). In some cases, the narrow remaining lumen was filled with accessory phenolic compounds (Fig. 13). The inhomogeneous and increased absorbance values within the thickened $\mathrm{S} 2$ layer of fibres varied between $\mathrm{Abs}_{280 \mathrm{~nm}} 0.09$ and $\mathrm{Abs}_{280 \mathrm{~nm}} 0.42$ (Figs. 13-15). Even though the two- 
dimensional images confirm this heterogeneity, the three-dimensional image profiles clearly display an almost concentric sub-layering, the lowest values always occurring in lumen-adjacent wall regions (Figs. 13-15). The absorbance values of the compound middle lamella ranged from $\mathrm{Abs}_{280 \mathrm{~mm}} 0.55$ to $\mathrm{Abs}_{280 \mathrm{~mm}} 0.81$ and in cell corners from $\mathrm{Abs}_{280 \mathrm{~nm}} 0.81$ up to $\mathrm{Abs}_{280 \mathrm{~nm}}$ over 0.94 (Figs. 13-15). The absorbance values of vessel walls also indicated a heterogeneous lignin distribution with unusual high values especially in the compound middle lamella $\left(\mathrm{Abs}_{280 \mathrm{~nm}} 0.29\right.$ to $\mathrm{Abs}_{280 \mathrm{~nm}}$ 0.62) (Fig. 14). The S2-layer of vessels showed absorbance maxima of $\mathrm{Abs}_{280 \mathrm{~nm}} 0.42$ and for the cell corners values from $\mathrm{Abs}_{280 \mathrm{~mm}} 0.55$ to $\mathrm{Abs}_{280 \mathrm{~nm}} 0.94$ were detected (Fig. 14). While Singh and Schmitt (2000) documented a mostly mottled lignin distribution in intercorner and cell, corner middle, lamella regions in Hevea brasiliensis, our study revealed a more dispersed lignin distribution.

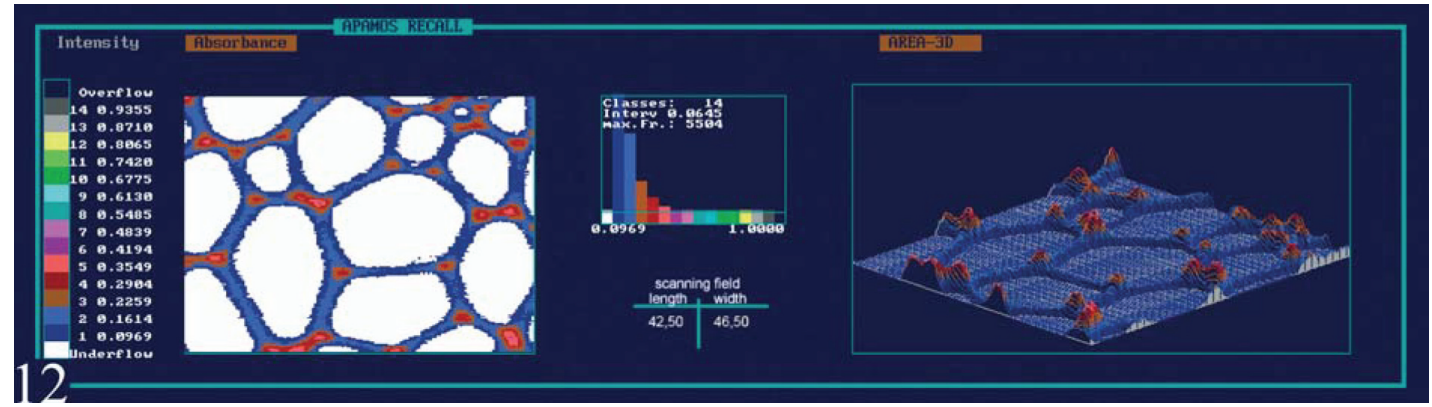

Figure 12 UV micrograph and 3D UV-microscopic scanning profile of unaffected xylem. The coloured pixels represent different UV-absorbance values within the fibre wall layers at $280 \mathrm{~nm}$ wavelength.

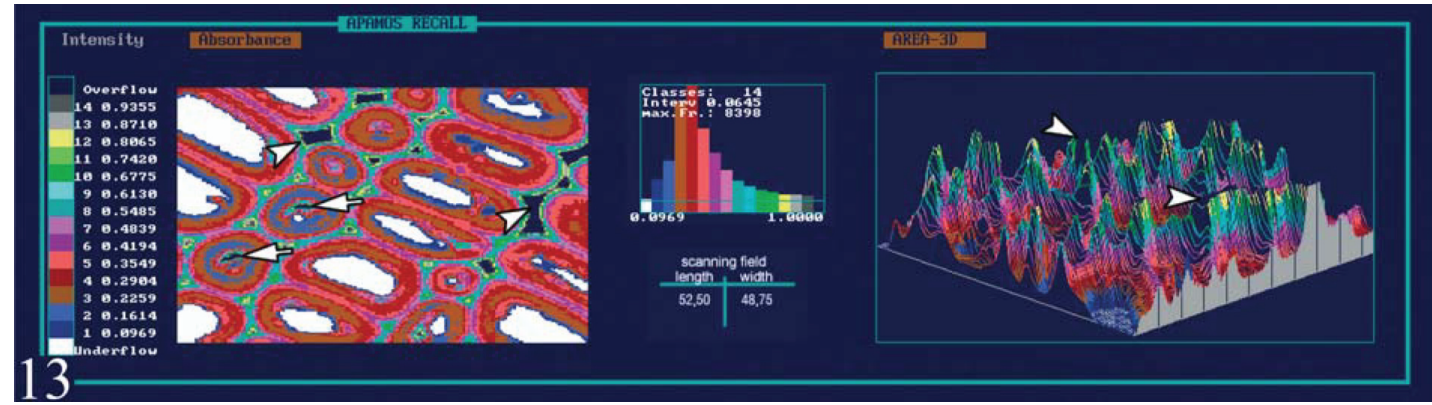

Figure 13 UV micrograph and 3D image profile of modified xylem with radially flattened fibres showing distinct wall thickenings; some fibres are filled with accessory phenolic compounds (arrows) and extremely high lignin concentrations in cell corner regions (arrowheads); 95 weeks after wounding.

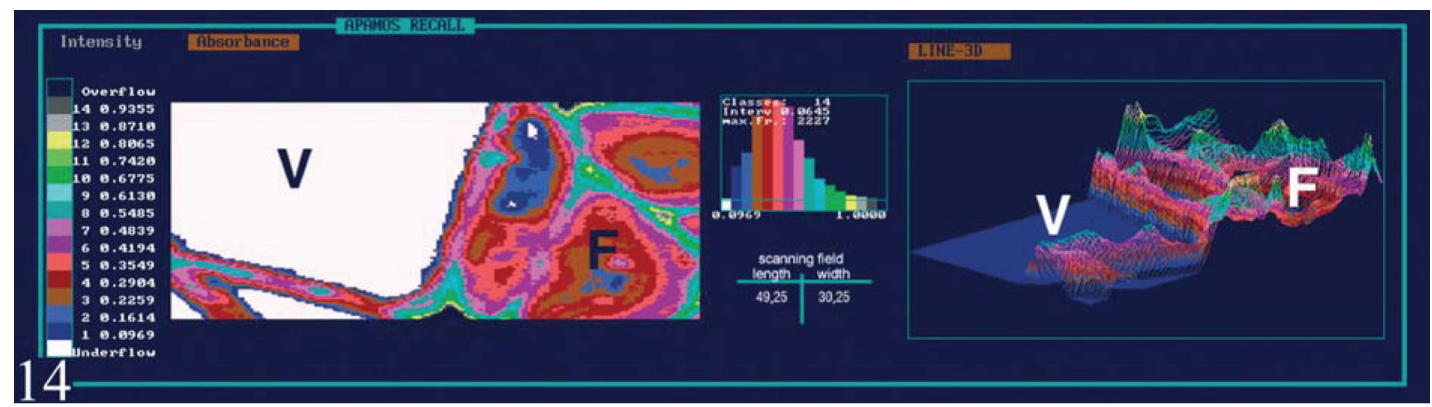

Figure 14 UV micrograph and 3D image profile of a vessel element (V) and adjacent fibres (F) within the transition zone 62 weeks after wounding. Fibres showing strong secondary wall thickenings; vessel walls displaying high lignin concentration. 


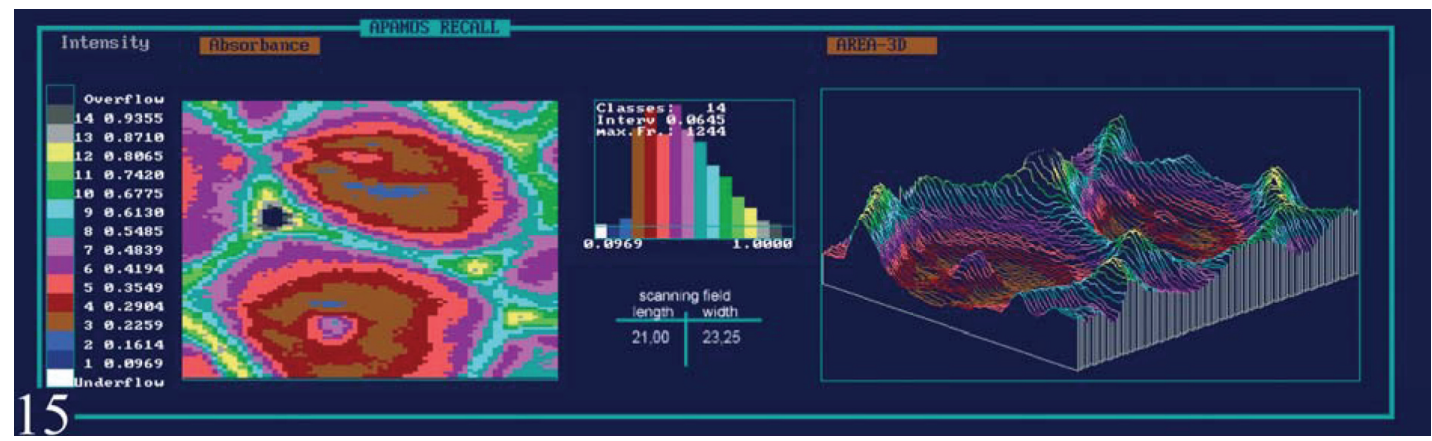

Figure 15 UV micrograph and 3D image profile of fibres showing extreme secondary wall thickenings; 62 weeks after wounding.

In hardwood fibres, the secondary wall is mainly composed of guaiacyl- and syringyl compounds resulting in a minimum absorbance at wavelengths from 250 to $260 \mathrm{~nm}$ and a maximum varying between 270-280 nm. The syringyl/guaiacyl ratio and the condensation of methoxyl groups determines the position of the absorbance maximum and also the absorbance intensity. With a higher guaiacyl lignin content and decreasing $\mathrm{MeO} / \mathrm{C}_{9}$ groups, the absorbance maximum shifts closer to $280 \mathrm{~nm}$ and the absorbance intensity increases (Fergus and Goring, 1970 a, b; Terashima et al., 1986 a, b; Fukazawa, 1992; Koch and Kleist, 2001; Takabe, 2002). In addition to syringyl and guaiacyl moieties, the xylem of Populus spp. contains p-hydroxy benzoic acid residues with a maximum absorbance at $260 \mathrm{~nm}$ wavelength (Musha and Goring, 1975). The semiquantitative interpretations of differences in the absorbance maxima between wounded and unaffected cells are therefore restricted and have to be related to the lignin composition as represented through the varying wavelengths of the maxima and in addition the ratio of the UV absorbance at $280 \mathrm{~nm}$ to that at $260 \mathrm{~nm}\left(\mathrm{~A}_{280} / \mathrm{A}_{260}\right)$. If p-hydroxy benzoic acid residues are associated with guaiacyl residues, the peak at $280 \mathrm{~nm}$ should flatten and if they are associated with syringyl residues the peak may shift to a lower wavelength or even disappear, as shown for eastern cottonwood (Musha and Goring, 1975).

Any influence of the detected condensed accessory phenolic extractives in fibres and ray parenchyma cells can be ignored. They show much higher absorbance values $\left(\mathrm{Abs}_{280 \mathrm{~nm}} 1,38\right)$ when compared to lignin and their absorbance maxima displayed a bathochromic shift to a wavelength of $284 \mathrm{~nm}$ to $286 \mathrm{~nm}$ and a slower decrease of the absorbance when compared to lignin.

The UV-absorbance behaviour of previously scanned tissue areas were characterized by point measurements with a spot size of $1 \mu \mathrm{m}$ and a wavelength between 240 to $400 \mathrm{~nm}$. In Figures 16-18, representative spectra of unaffected and modified fibre wall layers are shown. The spectra obtained for S2-layers of unaffected early- and latewood fibres displayed a less distinct relatively low peak absorbance at 270 to $272 \mathrm{~nm}$ (Fig. 16), corresponding with earlier studies (Fergus and Goring, $1970 \mathrm{a}$, b; Musha and Goring, 1975; Fukazawa, 1992). Even though the $\mathrm{A}_{280} / \mathrm{A}_{260}$ ratio (1.02) was slightly higher than revealed for other poplar species (Musha and Goring, 1975), it indicates a low content of predominantly syringyl-type lignin associated with p-hydroxy benzoic acid residues. The peak absorbance at $278 \mathrm{~nm}$ measured in cell corner regions and a ratio of 1.29 verifier the highest lignin concentration of mainly guaiacyl lignin within the unaffected xylem (Fig. 18). Our measurement within the S2 and cell corner regions are in good agreement with general lignification concepts (e.g. Fergus and Goring, 1970 a, b; Musha and Goring, 1975; Terashima et al., 1986 a, b, 1993; Donaldson, 2001; Donaldson et al., 2001; Grünwald et al., 2002 a; Koch and Kleist, 2001; Takabe, 2002). The spectra taken in middle lamella regions (Fig. 17) with an almost unchanged peak absorbance at $272 \mathrm{~nm}$ and the slightly higher $\mathrm{A}_{280} / \mathrm{A}_{260}$ ratio (1.09) indicates only a faintly enhanced lignin content and a nearly identical lignin composition when compared with the S2. A shift of the peak absorbance in middle lamella regions of poplar towards $272 \mathrm{~nm}$ at the end of cell differentiation, due to an increased incorporation of syringyl residues, was 
shown by Grünwald et al. (2002 a). However, a higher relative abundance of guaiacyl lignin moieties in hardwood middle lamellae has been frequently was regularly described (e.g. Fergus and Goring, 1970 b; Musha and Goring, 1975; Terashima, 1986 a, b, 1993).

Within the distinctively thickened secondary wall of transition zone fibres, the absorbance maxima varied between 272 and $274 \mathrm{~nm}$ (Fig. 16). Simultaneously, the $\mathrm{A}_{280} / \mathrm{A}_{260}$ ratio increased up to mean values of 1.22 , verifying a reduced amount of associated p-hydroxy benzoic acid subunits and a distinct incorporation mostly of guaiacyl moieties. The mean $\mathrm{A}_{280} / \mathrm{A}_{260}$ ratio in middle lamella regions of modified fibres increased $\left(\mathrm{A}_{280} / \mathrm{A}_{260} 1.25\right)$ and the peak absorbance shifted towards higher wavelengths (274 to $276 \mathrm{~nm}$ ) (Fig. 17) reflecting the same effect as already described for the S2. The spectra taken in cell corner regions displayed absorbance maxima between wavelengths of 276 to $280 \mathrm{~nm}$ (Fig. 18), and the $\mathrm{A}_{280} / \mathrm{A}_{260}$ ratio (1.28) was not significantly different from cell corners of fibres from unaffected fibre walls. These measurements point to a higher amount of lignin, whereas its composition remains almost the same.
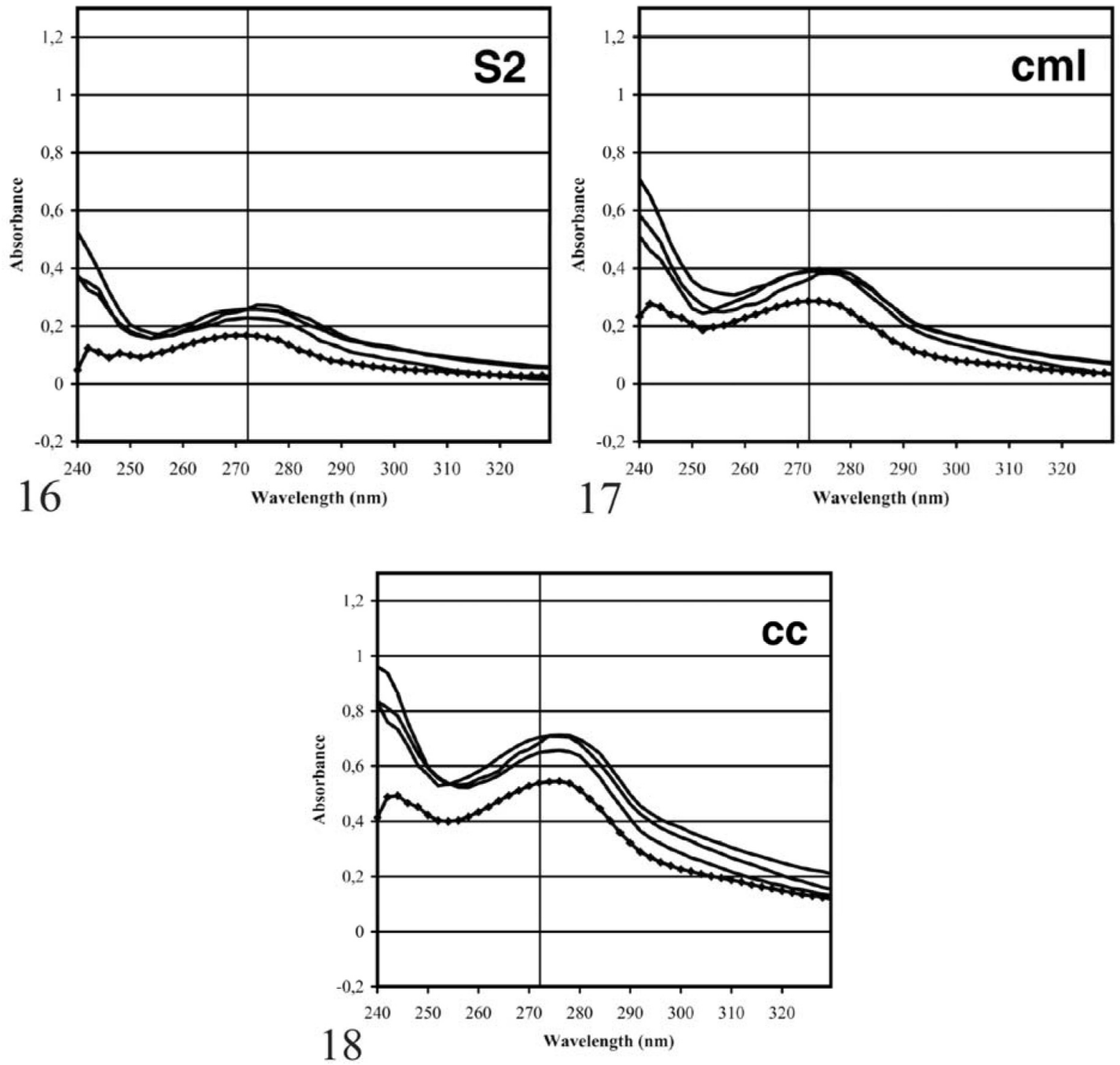

Figures 16-18 Representative UV absorbance spectra of fibre wall layers of controls (- - -) and after different periods of wound response. Vertical line indicates a wavelength of $272 \mathrm{~nm}$. 
It can be concluded that wounding induces a distinctive wall thickening in xylem fibres differentiating at the time of wounding and a modified lignin topochemistry, mainly restricted to secondary wall and compound middle lamella regions. This wound response adds a further mechanism to the well known compartmentalization processes and contributes to an increased resistance.

\section{ACKNOWLEDGEMENTS}

We thank Ms. T. Potsch and Ms. C. Waitkus for supporting the work. The work was partly funded by the "Deutsche Forschungsgemeinschaft/DFG" (GR 1788/2-1).

\section{REFERENCES}

Bauch, J.; Seehann, G.; Fitzner, H. 1976. Microspectrophotometrical investigations on lignin of decayed wood. Material und Organismen, Beiheft 3: 141-152.

Bauch, J.; Shigo, A.L.; Starck, M. 1980. Wound effects in the xylem of acer and betula species. Holzforschung 34: 153-160.

Bland, D.E.; Hillis, W.E. 1969. Microspectrophotometric investigations of lignin and polyphenol distribution in wood sections. Appita 23: 204-210.

Brown, C.L.; Sax, K. 1962. The influence of pressure on the differentiation of secondary tissues. American Journal of Botany 49: 683-691.

Bucciarelli, B.; Ostry, M.E.; Fulcher, R.G.; Anderson, N.A.; Vance, C.P. 1999. Histochemical and microspectrophotometric analyses of early wound responses of resistant and susceptible Populus tremuloides inoculated with Entoleuca mammata («a Hypoxylon mammatum). 'Canadian Journal of Botany 77: 548-555.

Buntrock, M. 1989. Anatomische Untersuchungen über die Wundreaktion der Pappel. Diploma Thesis, University of Hamburg, Germany.

Donaldson, L.A. 1992. Lignin distribution during late wood formation in Pinus radiata D. Don. IAWA Journal 13: 381 - 387.

Donaldson, L.A. 2001. Lignification and lignin topochemistry - an ultrastructural view. Phytochemistry 57: 859-873.

Donaldson, L.A.; Hague, J.; Snell, R. 2001. Lignin distribution in coppice poplar, linseed and wheat straw. Holzforschung 55: 379-385.

Fergus, B.J.; Goring, D.A.I. 1970 a. The location of guaiacyl and syringyl lignins in birch xylem tissue. Holzforschung 24: 113-117.

Fergus, B.J.; Goring, D.A.I. 1970 b. The distribution of lignin in birch wood as determined by ultraviolet microscopy. Holzforschung 24: 118-124.

Fink, S. 1999. Pathological and regenerative plant anatomy. Gebrüder Borntraeger, Berlin, Stuttgart. 
Frankenstein, C.; Schmitt, U.; Waitkus, W.; Eckstein, D. 2005. Wound callus formation - a microscopic study on poplar (Populus tremula L. x Populus tremuloides Michx.). Journal of Applied Botany and Food Quality 79: 44 - 51.

Fukazawa, K. 1992. Ultraviolet microscopy. In: Lin, S.Y.; Dence C.W., eds. Methods in lignin chemistry. Springer Verlag, Berlin: 110-121.

Grünwald, C.; Ruel, K.; Joselau, J.P.; Fladung, M. 2001. Morphology, wood structure and cell wall composition of rolC transgenic and non-transformed aspen trees. Trees 15: 503-517.

Grünwald, C.; Stobbe, H.; Schmitt, U. 2002. Entwicklungsstufen der seitlichen Wundüberwallung von Laubgehölzen. Forstwissenschaftliches Zentralblatt 121: 50-58.

Grünwald, C.; Ruel, K.; Kim, Y.S.; Schmitt, U. 2002 a. On the cytochemistry of cell wall formation in poplar trees. Plant Biology 4: 13-21.

Grünwald, C.; Ruel, K.; Schmitt, U. 2002 b. Differentiation of xylem cells in rolC transgenic aspen trees - a study of secondary cell wall development. Annals of Forest Science 59: 679-685.

Kaufert, F. 1937. Factors influencing the formation of periderm in Aspen. American Journal of Botany 24: 24-30.

Koch, G.; Kleist, G. 2001. Application of scanning UV microspectrophotometry to localise lignins and phenolic extractives in plant cell walls. Holzforschung 55: 563-567.

Koch, G.; Grünwald, C. 2004. Application of UV microspectrophotometry for topochemical detection of lignin and phenolic extractives in wood fibre cell walls. In: Schmitt, U.; Ander, P.; Barnett, J.R.; Emons, A.M.C.; Jeronimidis, G.; Saranpää, P.; Tschegg, S., eds. Wood fibre cell walls: Methods to study their formation, structure and properties. Swedish University of Agricultural Science, Uppsala: 119-130.

Liese, W.; Dujesiefken, D. 1989. Wundreaktionen bei Bäumen. Tharandt: Tagungsbericht, 2. Symposium, Ausgewählte Probleme der Gehölzphysiologie - Gehölze, Mikroorganismen und Umwelt: 75-80.

Liese, W.; Dujesiefken, D. 1996. Wound reactions of trees. In: Raychaudhuri, S.P.; Maramorosch, K., eds. Forest trees and palms: Diseases and control. IBH publishing, Oxford, New Delhi, Calcutta: 21-35.

Lowerts, G.; Wheeler, E.A.; Kellison, R.C. 1986. Characteristics of wound-associated wood of Yellow-Poplar (Lirodendron tulipifera L.). Wood and Fiber Science 18: 537-552.

Mullick, D.B. 1977. The non-specific nature of defence in bark and wood during wounding, insect and pathogen attack. Recent Advances in Phytochemistry 11: 395-441.

Musha, Y.; Goring, D.A.I. 1975. Distribution of syringyl and guaiacyl moieties in hardwoods as indicated by ultraviolet microscopy. Wood Science and Technology 9: 45-58.

Okuyama, T.; Takeda, H.; Yamamoto, H.; Yoshida, M. 1998. Relation between growth stress and lignin concentration in the cell wall: ultraviolet microscopic spectral analysis. Journal of Wood Science 44: 83-89. 
Pearce, R.B. 2000. Decay development and its restriction in trees. Journal of Arboriculture 26: 1-11.

Rademacher, P.; Bauch, J.; Shigo, A.L. 1984. Characteristics of xylem formed after wounding in Acer, Betula and Fagus. IAWA Bulletin 5: 141-151.

Saka, S.; Goring, D.A.I. 1988. Localization of lignins in wood cell walls. In: Higuchi, T., ed. Biosynthesis and Biodegradation of wood components. Academic Press, New York: 51-62.

Schmitt, U.; Liese, W. 1990. Wound reaction of the parenchyma in Betula. IAWA Bulletin 11: 413-420.

Schmitt, U.; Liese, W. 1992. Seasonal influences on early wound reactions in Betula and Tilia. Wood Science and Technology 26: 405-412.

Schmitt, U.; Liese, W. 1993. Response of xylem parenchyma by suberization in some hardwoods after mechanical injury. Trees 8: 23-30.

Schmitt, U.; Möller, R.; Eckstein, D. 2000. Seasonal wood formation dynamics of Beech (Fagus sylvatica L.) and Black Locust (Robinia pseudoacacia L.) as determined by the "Pinning" technique. Journal of Applied Botany 74: 10-16.

Scott, J.A.N.; Procter, A.R.; Fergus, B.J.; Goring, D.A.I. 1969. The application of ultraviolet microscopy to the distribution of lignin in wood. Description and validity of the technique. Wood Science and Technology 3: 73-92.

Sharon, E.M. 1973. Some histological features of Acer saccharum wood formed after wounding. Canadian Journal of Forest Research 3: 83-89.

Shigo, A.L. 1984. Compartmentalization: A conceptual framework for understanding how trees grow and defend themselves. Annual Review of Phytopathology 22: 189-214.

Shigo, A.L.; Marx, H.G. 1977. Compartmentalization of decay in trees. USDA/ Forest Service and Agriculture Information Bulletin 405: 1-73.

Shortle, W.C. 1979. Compartmentalization of decay in red maple and hybrid poplar trees. Phytopathology 69: 410-413.

Singh, A.P.; Schmitt, U. 2000. High variability in the distribution of lignin in the middle lamella of Rubber-wood (Hevea brasiliensis) cells. In: Kim, Y.S., ed. New horizons in wood anatomy. Chonnam Nat’1 University Press, Kwangju: 203-207.

Soe, K. 1959. Anatomical studies of bark regeneration following scoring. Journal of the Arnold Arboretum 40: 260-267.

Spurr, A.R. 1969. A low viscosity epoxy resin embedding medium for electron microscopy. Journal of Ultrastructural Research 26: 31-43.

Takabe, K. 2002. Cell walls of woody plants: Autoradiography and ultraviolet microscopy. In: Chaffey, N., ed. Wood formation in trees. Taylor \& Francis, London: 159-177.

Terashima, N.; Fukushima, K.; Takabe, K. 1986 a. Heterogeneity in formation of lignin. VIII. An autoradiographic study on the formation of guaiacyl and syringyl lignin in Magnolia kobus DC. Holzforschung 40: 101-105. 
Terashima, N.; Fukushima, K.; Tsuchiya, S.; Takabe, K. 1986 b. Heterogeneity in formation of lignin. VII. An autoradiographic study on the formation of guaiacyl and syringyl lignin in poplar. Journal of Wood Chemistry and Technology 6: 495-504.

Terashima, N.; Fukushima, K.; Takabe, K. 1993. Comprehensive model of the lignified plant cell wall. In: Jung, H.G.; Buxton, D.R.; Hatfield, R.D.; Ralph, J., eds. Forage cell wall structure and digestibility. ASA-CSSA-SSSA, WI, Madison: 247-270.

Trockenbrodt, M.; Liese, W. 1991. Untersuchungen zur Wundreaktion in der Rinde von Populus tremula L. und Platanus x acerifolia (Ait.) Willd. Angewandte Botanik 65: 279-287. 